J. Lake Sci. (湖泊科学) , 2019, 31(6): 1783-1796

DOI 10. 18307/2019. 0623

(c) 2019 by Journal of Lake Sciences

\title{
青海湖湖滩岩的岩石学特征及其形成机制”
}

\author{
陈 骥 ${ }^{1,2}$, 姜在兴 ${ }^{2}$, 张万益 ${ }^{1}$, 刘 超 $^{2}$, 许文茂 ${ }^{3}$ \\ (1: 中国地质调查局发展研究中心, 北京 100037) \\ (2: 中国地质大学 (北京), 北京 100083) \\ (3: 北京科技大学, 北京 100083)
}

\begin{abstract}
摘 要: 以青海湖的湖滩岩为研究对象, 通过显微镜观察、扫描电镜、矿物阴极发光性观察和电子探针等分析方法研究了 湖滩岩的岩石学特征和形成机制. 湖滩岩胶结物主要由暗色纹层和文石针组成, 识别出五类胶结物晶体和三类胶结物组 构. 在暗色纹层中, 有发现包覆式和缠绕式生长的微生物. 微生物对泥晶方解石和黏土矿物起着生物稳定化作用 ( 障积作 用、捕获作用和粘结作用). 微生物生长过程中的新陈代谢影响了碳酸盐的溶解度, 从而导致产生碳酸盐矿物在微生物席 内的丝状体之间或沿着丝状体的沉淀作用. 从研究湖滩岩胶结物垂向上和横向上的变化规律人手, 发现胶结物的类型和 组构与水深、温度、盐度、水动力条件有一定关系. 破浪带和碎浪带的水深、温度、盐度适宜, 为微生物作用最强的水动力 带. 通过对青海湖湖滩岩中的微生物作用特征及其发育模式的研究, 认为湖滩岩中胶结物的形成受到微生物作用的影响 较大,从而支持了微生物作用对碎屑岩早期成岩具有重要意义的假设.
\end{abstract}

关键词: 湖滩岩;胶结物;成岩作用;青海湖;微生物

\section{The petrological characteristics and formation mechanism of Lake Beachrock in Lake Qinghai}

\author{
CHEN Ji ${ }^{1,2}$, JIANG Zaixing ${ }^{2}$, ZHANG Wangyi ${ }^{1}$, LIU Chao ${ }^{2} \&$ XU Wenmao ${ }^{3}$ \\ (1: Development Research Center of China Geological Survey, Beijing 100037, P.R.China) \\ (2: China University of Geosciences, Beijing 100083, P.R.China) \\ (3: University of Science and Technology Beijing, Beijing 100083, P.R.China)
}

\begin{abstract}
The lake beachrock in Lake Qinghai as the research object, through microscope, SEM, mineral cathode luminance observation and electron probe analysis method to study the characteristics and precocious mechanism of lake beachrock. The beachrock cement is mainly composed of dark grain layers and aragonite needles. There are five kinds of cement crystals and three kinds of cement fabric. There is coating, voluble and conglutinating growth of microbes in the lake beachrock cement. Microorganisms for micritic calcite and clay mineral have a biological stabilization effect (barrier, and the roles of capture and bonding effect). The metabolism in the microbial growth will change the carbonate solubility and resulting in carbonate minerals is produced by the filaments in microbial mat or between precipitations along the filaments. From the lake beach rock cement on the lateral and vertical changes, it is found that the type and texture of the cement are related to water depth, temperature, salinity and hydrodynamic conditions. Water depth, temperature, and salinity are suitable in swash zone and breaker zone where microbial activities arethe strongest. Through the research of microbial characteristics and developmental pattern of beachrock cement in Lake Qinghai, we concluded that cement in the lake beachrock is affected by the microbial action, which support the biological role of clastic rock in early diagenetic hypothesis that it is of great significance.
\end{abstract}

Keywords: Lake beachrock; cement; diagenesis; Lake Qinghai; microbe

* 国家地质调查成果集成与规划项目 (DD20190464) 和国家水体污染控制与治理科技重大专项 (2017ZX05009-002) 联合资助. 2019-04-09 收稿; 2019-05-09 收修改稿. 陈䩀 (1988 ), 男, 博士后; E-mail: chenji2007@ foxmail. com. 
在现代海岸的滨岸带发育着一种特殊的岩石一一海滩岩 ${ }^{[1]}$. 海滩岩可指示古海岸线的位置, 并能反映 一定的古气候条件 ${ }^{[2-3]}$. 海滩岩胶结物作为早成岩阶段的产物, 对它的研究对于认识碎屑岩形成过程具有重 要意义 ${ }^{[4-6]}$. 通过研究海滩岩的形态和分布特征, 可以反映全新世或者更新世的全球海平面变化特征 ${ }^{[7-9]}$. 通 过研究不同纬度的滩岩胶结物的组构、成分和微观特征, 可以揭示海滩岩的形成原因 ${ }^{[10]}$. 国内学者发现中 国的海滩岩形成于潮间带, 胶结物多为高镁方解石和文石,指示了平均海平面的变化 ${ }^{[11-13]}$. 这种早成岩作用 的产物在国内外湖泊的滨岸带也有发现 ${ }^{[1-15]}$. Swainson 等 ${ }^{[15]}$ 利用中子和 $\mathrm{x}$ 射线粉末衍射法分析发现海滩岩 的碳酸盐基团是通过一个线性和一个分叉的氢键与一个水分子相结合而形成. 通过对 Ore 湖的湖滩岩进行 研究, Binkley 等 ${ }^{[16]}$ 和 Last 等 $^{[17]}$ 认为湖滩岩发育在渗流带, 胶结物中的针状方解石是由于化学沉淀作用而 形成. Dupraz 等 ${ }^{[18]}$ 和 Erginal 等 ${ }^{[19]}$ 提出湖滩岩胶结物的形态和位置与微生物的作用有关. 通过对 Iznik 湖的 湖滩岩进行扫描电镜、EDS 和 OSL 等测试分析, Muhammed 等 ${ }^{[20]}$ 发现该湖滩岩由泥晶包壳和文石针组成, 并 识别出湖滩岩的胶结物分别形成于全新世早期、全新世气候适宜期、全新世中期和全新世晚期.

目前, 已有的研究显示国内的湖滩岩发育在青海湖 ${ }^{[21]}$ 、西藏纳木错湖 ${ }^{[22-23]}$ 、新疆赛里木湖 ${ }^{[24]}$ 等湖岸地 带, 其他地方尚未发现. 李永春 ${ }^{[21]}$ 认为由于湖滨浅水区的碳酸盐极易过饱和就地沉淀, 渗透充填在湖滩砂 砾孔隙中, 胶结成岩形成新近沉积岩一一湖滩岩. 朱大岗等 ${ }^{[22]}$ 认为“湖滩岩”可定义为“一种发育在湖滩带 上拍岸浪和周期性湖水涨落影响区间石化了的湖相沉积物”. 湖滩岩的机械颗粒组分可以是多种多样的, 从 含火山岩、花岗岩、砂岩、变质岩岩屑, 到全是碳酸盐岩碎屑; 砂和砾都胶结得很好, 胶结物几乎全为微细粒 碳酸盐物质. 国内学者普遍认为湖滩岩的形成与局部湖水咸化导致水中钙质含量增高有关 ${ }^{[21-24]}$. 这一点认 识与国外学者的认识存在明显的争议. 因此, 本文通过野外观察、镜下薄片观察、扫描电镜观察和电子探针 分析, 详尽地分析了青海湖湖滩岩胶结物的类型和组构特征, 并初步探讨了胶结物与微生物作用之间的关 系,总结了湖滩岩的变化规律和形成过程.

\section{1 研究区概况}

青海湖 ( $36^{\circ} 32^{\prime} \sim 37^{\circ} 15^{\prime} \mathrm{N}, 99^{\circ} 36^{\prime} \sim 100^{\circ} 16^{\prime} \mathrm{E}$ ) 是我国最大的内陆高原微咸水湖泊 ${ }^{[25]}$, 地处青藏高原的东 北部. 青海湖的长轴方向 (近东一西向) 约为 $106 \mathrm{~km}$, 横轴方向 (近南一北向) 约为 $63 \mathrm{~km}$, 湖面海拔为 $3193 \sim$ $3198 \mathrm{~m}$, 面积为 $4264 \sim 4473 \mathrm{~km}^{2}$, 环湖周长约 $360 \mathrm{~km}$. 湖面东西长, 南北窄, 呈近椭圆形, 长轴北西西向约 $315^{\circ[26]}$. 湖水平均深度 $21 \mathrm{~m}$, 最大水深 $32 \mathrm{~m}$, 蓄水量达 1000 亿 $\mathrm{m}^{3}$ 左右.

湖区四周被高山所环抱: 北面是近东西走向的大通山,主峰海拔 $4200 \mathrm{~m}$ 以上. 湖区南面是呈北西西向 延伸的青海南山. 自西而东可将青海南山分为三段: 西段由三列平行山脉组成, 它们是切十字大坂 (海拔 $3500 \mathrm{~m}$ )、中吾农山 (海拔 3800 4300 m) 和茶卡北山 ( 4300 4700 m ${ }^{[27]}$. 山脉向西延伸, 成为青海湖盆地与 柴达木盆地的分水岭; 中段是塔温山、哈堵山和龙保欠山 (海拔 $4200 \sim 4500 \mathrm{~m}$ ), 成为青海湖盆地与南侧的共 和盆地的分水岭; 东段是加拉山 (海拔 3800 4000 m), 与野牛山共同组成青海湖盆地与贵德盆地的分水岭 (图 1A). 环青海湖地区的滨岸砾石滩、沙质滩和砂砾质滩较为发育, 也为湖滩岩的形成提供了良好的物质 基础 ${ }^{[28-29]}$. 本次考察重点对青海湖西岸的二郎尖一江西沟一黑马河一线的湖滩岩进行野外观察和采样, 总共 有 5 个野外观测和采样点 (图 1B).

\section{2 研究方法}

对青海湖湖滩岩的岩石学特征分析主要分成两个部分: 宏观的露头特征和微观的镜下特征. 宏观的露头 特征主要是分析湖滩岩的沉积构造; 微观的镜下特征主要是分析湖滩岩的胶结物特征. 薄片分析、阴极发光与 扫描电镜及能谱测试在中国地质大学 (北京) 能源学院海相储层演化与油气富集机理教育部重点实验室完成, 电子探针分析在清华大学材料院中心实验室完成. 用于阴极发光特征和电子探针分析的岩石薄片厚 $30 \mu \mathrm{m}$, 双 面抛光, 用环氧树脂粘结在标准载玻片上, 不加盖玻片. 阴极发光特征分析采用 RELION CL 冷阴极发光系统, 选择束电压为 $12 \mathrm{kV}$ 、束电流为 $300 \mu \mathrm{A}$ 、曝光时间为 $1.1 \mathrm{~s}$. 分析元素成分所使用的电子探针显微分析仪型号为 EPMA-8050G, 分析时的工作电压为 $15 \mathrm{kV}$, 电流强度 $25 \mu \mathrm{A}$, 束斑直径小于 $1 \mu \mathrm{m}$, 每个探针点的检测时间大于 2 h. 观察胶结物组构和微生物形态所用的扫描电镜型号为 JXA-8100, 能谱仪型号为 INCA. 


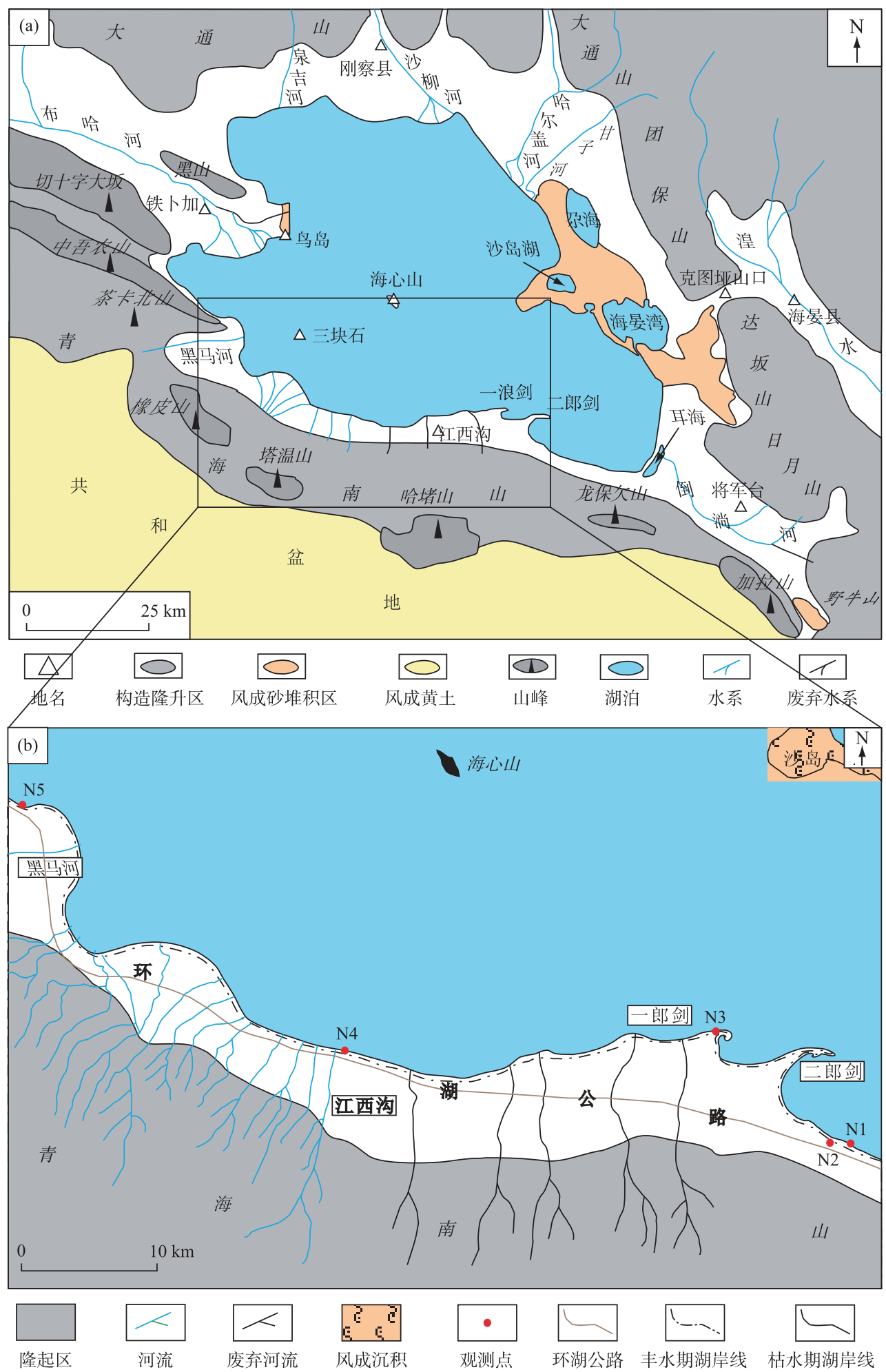

图 1 青海湖地理位置 (A) 和湖滩岩的采样位置 (B)

Fig.1 Geographical(A) and the sampling sites position in lake beachrock(B) in Lake Qinghai 


\section{3 青海湖湖滩岩的岩石学特征}

\section{1 湖滩岩的野外特征}

青海湖湖滩岩出露位置均在青海湖的湖滨岸线附近,位于湖积台地或古湖岸堤上. 其中以湖区东南部 的二郎剑和西北部的铁卜加一带发育最好. 本次所发现的湖滩岩多发育在一级和二级阶地上. 沉积构造多 为斜层理或平行层理,整体上表现为下细上粗的反旋回 (图 $2 \mathrm{~A} 、 \mathrm{~B} 、 \mathrm{C}$ 和 D). 胶结良好成岩的湖滩岩与上覆 的湖滨相的湖滩砂并无明显界限,碎屑成分与湖滨松散沉积物完全一致,仅存在成岩与否的差别(图 $2 \mathrm{G}$ ).
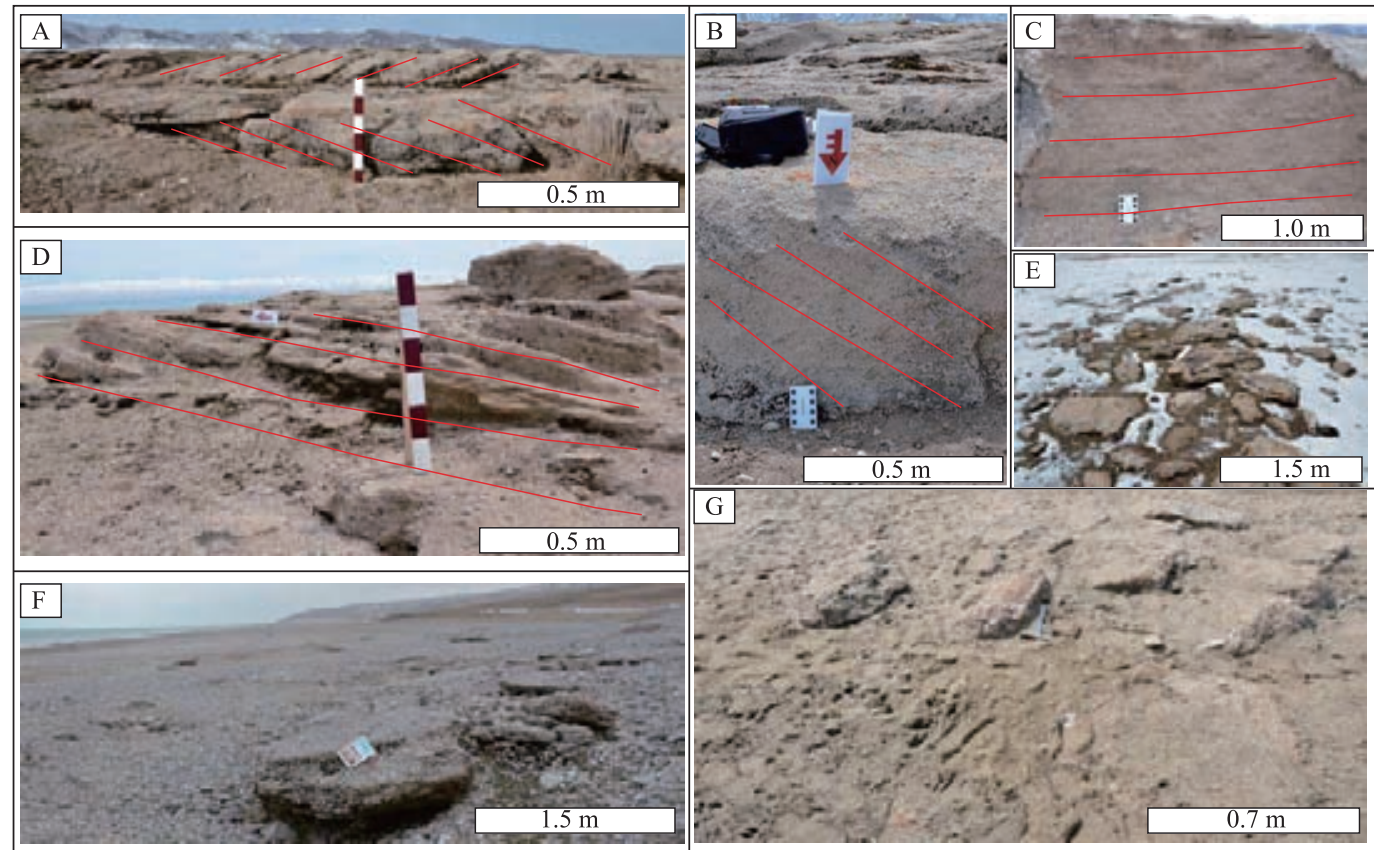

图 2 青海湖湖滩岩野外照片: (A) 发育两组不同倾向的交错层理,观测点 $\mathrm{N} 1$;

(B) 为图 A 的局部放大,可见高角度交错层理; (C) 发育平行层理和韵律层理,观测点 $\mathrm{N} 2$;

(D) 为图 A 上半部分的放大,指示了层理向陆地倾斜; (E) 湖滩岩被地表的砂泥所覆盖,观测点 N3;

(F) 砾质湖滩岩, 观测点 $N 4 ;(G)$ 湖滩岩被地表的砂砾所覆盖, 观测点 N5

Fig.2 Photographs of beachrock deposits: (A) Cross-bedded beachrock at the lakeward end of beachrock deposit, the observation point N1. Note there exist two different dip directions of layers. (B) Enlargement of (A). Note high angle cross beddings. (C) Horizontal bedding and rhythmic layering, the observation point N2.

(D) Enlargement of the top of (A). Note the dip direction of the layer towards land.(E) Beachrock which position is the nearest of lake coast is covered by sand and mud, the observation point N3.

(F) The grains of beachrock is composed of limestone, the observation point N4.

(G) Beachrock whose position is the nearest of lake coast is covered by sand, the observation point N5

宗务隆山一带的上石炭统中吾农山群为典型的槽型石炭系沉积. 下部以碎屑岩为主, 上部以碳酸盐岩 为主. 出露于茶卡北山和黑马河及加拉山一带的下三叠统, 下部以英安岩和流纹英安岩为主; 中上部以砾岩 和砂砾岩为主 ${ }^{[30]}$. 对比二郎剑湖滩岩和铁卜加湖滩岩, 二者可直接从肉眼发现明显的区别. 二郎剑湖滩岩 颜色呈浅棕褐色, 岩石颗粒以砾砂为主, 岩性比较复杂, 以岩浆岩为主, 说明物源来自茶卡北山和加拉山下 三叠统的砂砾岩; 铁卜加湖滩岩颜色呈浅灰白色, 岩石颗粒以磨圆很好的砾石为主, 岩性比较单一, 基本上 都是灰岩,说明物源来自宗务隆山的上石炭统的灰岩 (图 $2 \mathrm{E}$ 和 F). 


\section{2 胶结物的类型和组构}

胶结物是表现湖滩岩成岩历史的重要记录. 薄片研究在识别成岩环境和确定碳酸盐岩的共生序列是极 为重要的. 用传统的光学显微镜在偏振光下能观测晶体的形状和岩石组构等光学性 质 $^{[31]}$. 用扫描电镜能够 更细致地观测晶体的形态特征. 用阴极发光显微镜能观测胶结物晶体的主要生长形态和过程. 胶结物类型 的描述和识别是以胶结物晶体的排列和形态为基础的. 根据胶结物晶体的形状、尾端、晶型和大小等特征, 在显微镜下识别出五类胶结物晶体: 杂乱针状晶体、纤维状晶体、共轴柱状晶体、叶片状晶体和放射状晶体 ( 图 3).

杂乱针状晶体顶端是尖的,长度约 $100 \mu \mathrm{m}$, 宽度 $<10 \mu \mathrm{m}$ (图 $3 \mathrm{~A} 1$ 和 A2). 纤维状晶体顶端是圆柱状的 (长宽比 $>6: 1$, 宽度 $>10 \mu \mathrm{m}$ ) (图 $3 \mathrm{~B} 1$ 和 B2). 杂乱针状晶体和纤维状晶体都是由文石针组成, 而二者最大 区别在于是否垂直底质生长 (纤维状晶体垂直底质生长). 共轴柱状晶体通常呈云雾状和混沌状, 呈波状消 光 (图 $3 \mathrm{C} 1$ 和 $\mathrm{C} 2$ ). 晶体一般大小为 $30 \sim 300 \mu \mathrm{m}$, 长宽比为 $1: 3 \sim 1: 10$. 叶片状晶体顶端像马牙状 (图 $3 \mathrm{D} 1$ 和 D2), 宽度约为 $10 \mu \mathrm{m}$, 长度超过 $100 \mu \mathrm{m}$, 长宽比为 $1.5: 1 \sim 6: 1$, 因而显得较宽. 放射状晶体由单晶体和集 合体组成放射状,形态上像单个或者复式的扇体. 单个扇体是由正延性的自形纤维晶体组成 (图 $3 \mathrm{E} 1$ 和 E2). 复式扇体是由多期次的自形纤维晶体和微晶晶体组成, 反映了文石一方解石的世代胶结 (图 3 F1 和 F2). 放射状晶体普遍具有一个或者两个核心, 核心为泥晶方解石颗粒, 文石针围绕着核心生长. 后两种胶结 物类型仅仅出现在铁卜加湖滩岩胶结物中.

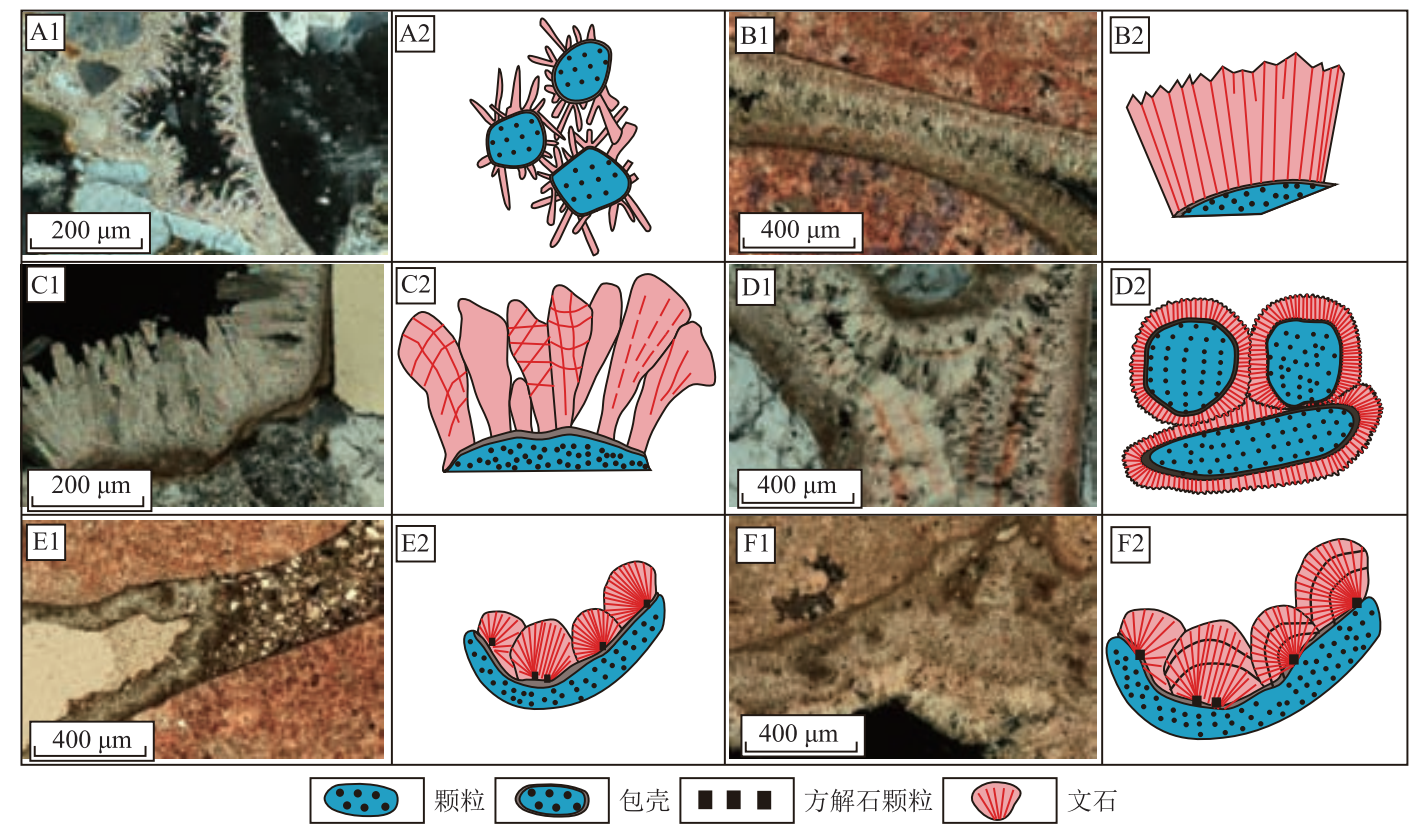

图 3 青海湖湖滩岩胶结物的晶体类型和模式图: (A1) 杂乱针状晶体显微照片;

(A2) 杂乱针状晶体模式图; (B1) 纤维状晶体显微照片; (B2) 纤维状晶体模式图;

(C1) 共轴柱状晶体显微照片; ( C2) 共轴柱状晶体模式图; (D1) 叶片状晶体显微照片; (D2) 叶片状晶体模式图; (E1) 单个扇放射状晶体显微照片; (E2) 单个扇放射状晶体模式图;

(F1)复式扇放射状显微照片; (F2)复式扇放射状晶体模式图

Fig.3 The types and models of crystals in Lake Qinghai beachrock cement:(A1) acicular crystals; (A2) the model of (A1); (B1) fibrous crystals; (B2) the model of (B1);(C1) radiaxial fibrous crystals; (C2) the model of(C1);(D1) radiaxial fibrous crystals;(D2) the model of(D1);(E1) bladed crystals; (E2) the model of(E1);(F1) botryoial crystals; (F2) the model of ( (F1) 
胶结物类型是最小的成分单元, 而胶结物组构是胶结物类型的集合体, 表现出特定的物质组成形式. 通 过研究胶结物、颗粒、基质和孔隙之间的空间关系, 将湖滩岩的胶结物组构可以分成三类: 等厚环边胶结物、 栉壳状胶结物和葡萄状环边胶结物 (图 4).

等厚环边胶结物的特征为单层胶结物围绕颗粒生长, 且厚度均一(图 $4 \mathrm{~A}, \mathrm{D}, \mathrm{G}$ ). 构成等厚环边胶结物 的晶体类型较多, 有针状晶体、纤维状晶体和柱状晶体等. 环边厚度一般在几十到几百微米左右. 等厚环边 胶结物发育范围最为广泛, 几乎在所有的湖滩岩上均可见. 栉壳状胶结物多发育在湖滩岩的中部, 主要是在 颗粒之间呈辐射状生长 (图 $4 \mathrm{~B}, \mathrm{E}, \mathrm{H}$ ). 葡萄状胶结物由微晶晶体和放射状的文石针或方解石组成 (图 4 C), 内部有不连续的薄纹层. 扫描电镜下的形态像一个个葡萄 (图 $4 \mathrm{~F}, \mathrm{I}$ ). 葡萄状胶结物仅出现在铁卜加湖 滩岩中. 所有胶结物在靠近颗粒的一侧均发育有泥晶包壳, 而包壳的厚度与底质 (颗粒的成分) 有一定关系. 底质为碳酸盐岩颗粒的包壳比底质为其他成分的颗粒的包壳厚.

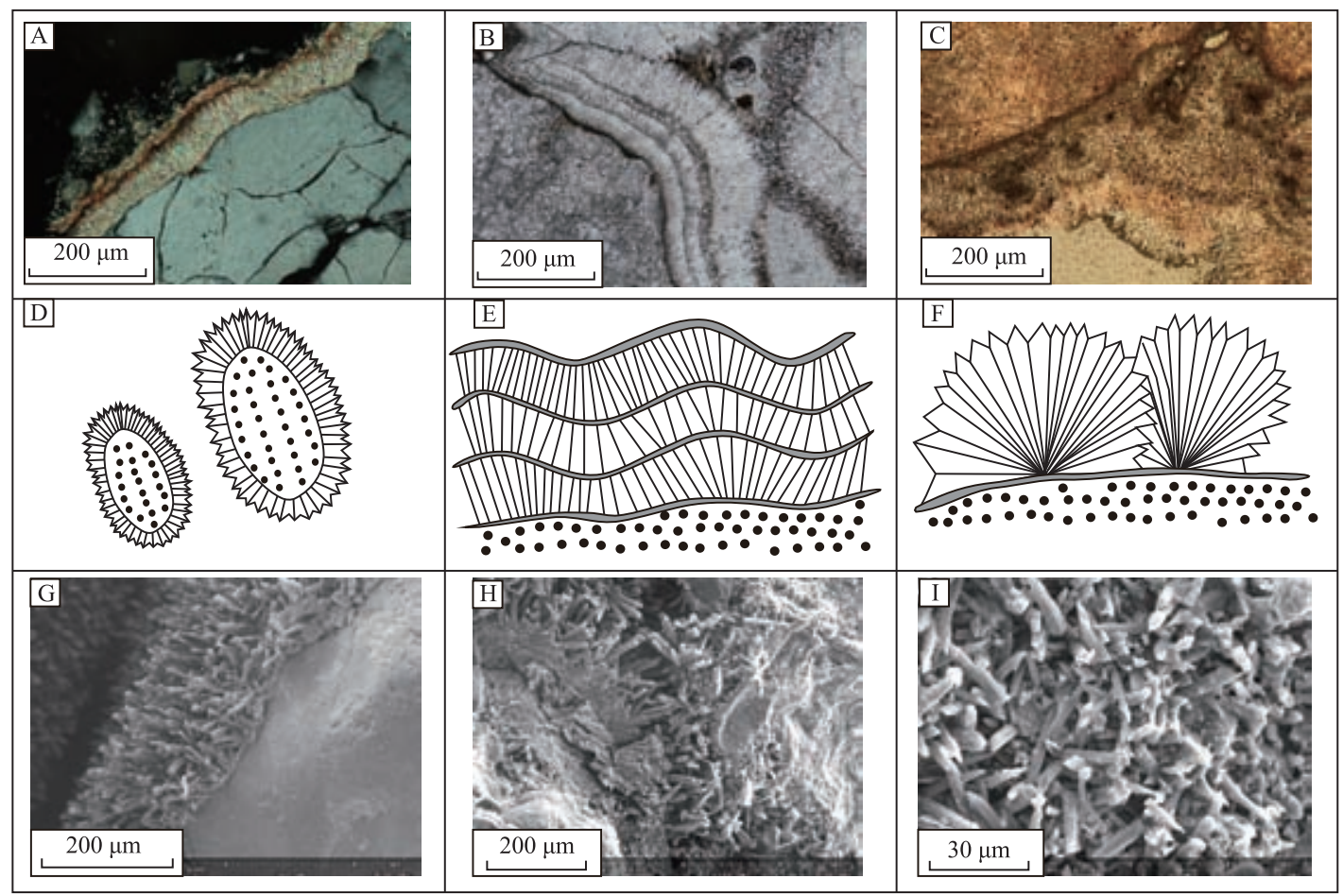

图 4 青海湖湖滩岩胶结物的组构类型和模式图: (A) 等厚环边胶结物; (B) 栉壳状胶结物;

(C) 葡萄状胶结物; (D) 等厚环边胶结物模式图; (E) 栉壳状胶结物模式图; (F) 葡萄状胶结物模式图;

( G) 等厚环边胶结物扫描电镜照片; ( H) 栉壳状胶结物扫描电镜照片; ( I) 葡萄状胶结物扫描电镜照片

Fig.4 The cement fabricsand models in lake beachrock of Lake Qinghai: (A) isopachous rim cement;

(B) ctenoid cement; (C) botryodial cement; (D) the model of (A) ; (E) the model of (B);

(F) the model of $(\mathrm{C}) ;(\mathrm{G})$ the SEM photograph of isopachous rim cement; (H) the SEM photograph of crust fibrous cement; (I) the SEM photograph of botryodial cement

在相同的测试条件下, 通常将样品的阴极发光强度分为极强、强、中等、弱、极弱一不发光 5 个等级 ${ }^{[32]}$. 由于海相环境沉积的碳酸盐岩组分往往无阴极发光或只有很弱的阴极发光, 而非海相环境沉积的碳酸盐岩 胶结物则通常具有较强的阴极发光 ${ }^{[32]}$. 粒状方解石基本上是等轴的 (图 $5 \mathrm{~A}$ 和 B), 反映低美含量的大气淡 水的地球化学条件 ${ }^{[33]}$. 青海湖湖滩岩的纤维状环边方解石胶结物完全无阴极发光, 甚至弱于具有极弱阴极 发光的泥晶基质 (图 5C). 由于阴极发光强度主要受控于流体中 Fe、Mn 元素含量的变化, 说明其生长过程中 流体性质发生了改变或具有相对较长的生长时间 ${ }^{[35]}$. 泥晶胶结物为弱阴极发光, 记录了低 $\mathrm{Mn}$ 含量的咸水 
特征, 指示了碳酸盐岩颗粒向泥晶转化; 纤维状环边方解石胶结物为无阴极发光, 指示了颗粒间和颗粒内部 胶结作用开始发育.

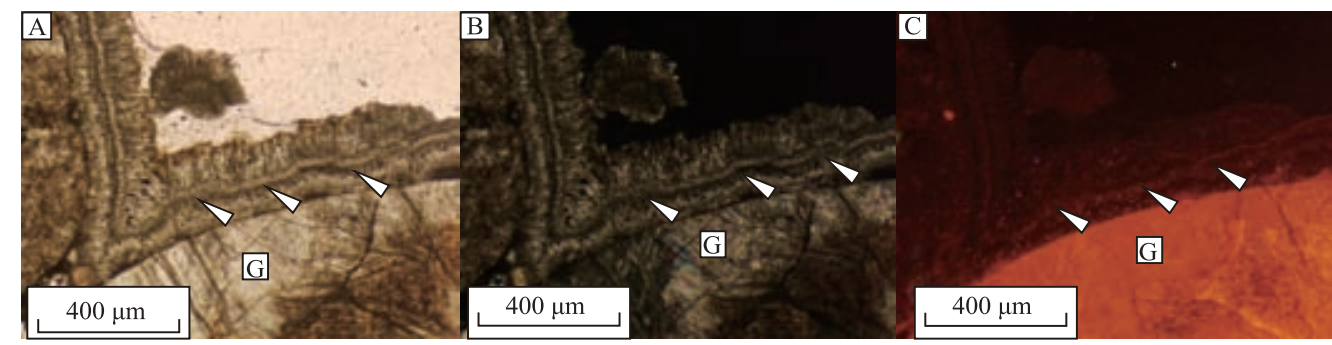

图 5 青海湖湖滩岩胶结物特征: (A) 单偏光显微照片; (B) 正交偏光显微照片; ( C) 阴极发光照片

Fig.5 The features of lake beachrock cement in Lake Qinghai:(A) Thin section images under plane polarized light; (B) Thin section images under perpendicular polarized light; (C) Thin section images in CL

青海湖湖滩岩中可见泥晶包壳十分发育, 电子探针能谱扫描图像 (图 6)显示, 泥晶包壳的分布区域与镁 元素的分布区域高度吻合, 结合前人研究 ${ }^{[16-17]}$ 认为可能与泥晶包壳中含有高镁方解石有关. 微生物从外部 $\mathrm{CaCO}_{3}$ 过饱和的水体中吸附二价离子, 使泥晶套中的微生物席或生物膜中 $\mathrm{Ca}^{2+}$ 和 $\mathrm{Mg}^{2+}$ 离子富集, 进一步提供 周围环境中 $\mathrm{CaCO}_{3}$ 的过饱和度.

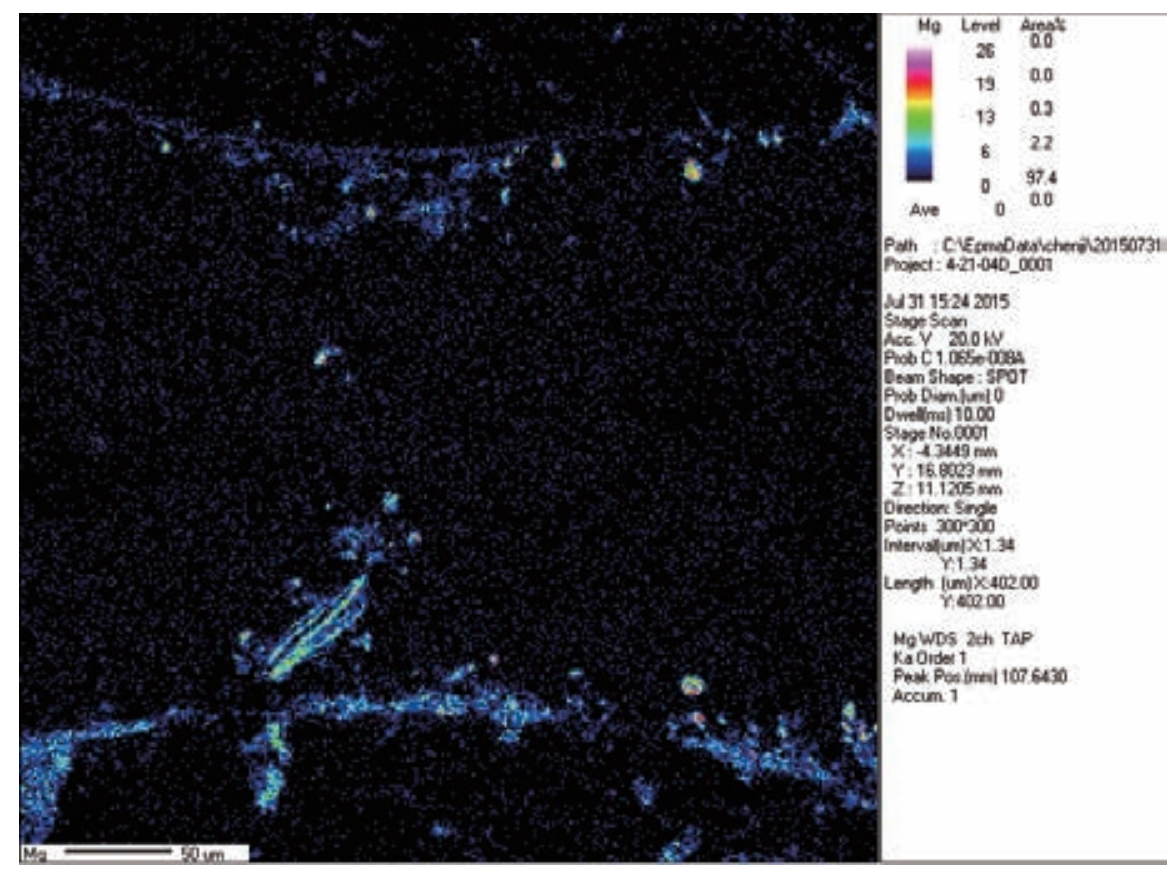

图 6 青海湖湖滩岩电子探针能谱扫描图中 $\mathrm{Mg}$ 元素分布特征

Fig.6 Mg distribution characteristics on electronic probe spectrum scanning map of lake beachrock in Lake Qinghai

\section{3 胶结物中的微生物作用}

通过扫描电镜对胶结物的观察, 发现了显微薄片的暗色纹层中富含大量的微生物. 在胶结物内部组构 中, 微生物的粘附作用和生长总是持续发生. 扫描电镜对胶结物观察结果, 发现有三种生长方式的微生物: 
包覆式生长、缠绕式生长和粘附式生长的微生物.

包覆式生长的微生物形态上疑似附枝菌, 具有分叉的叶状放射丛 (长 300 $800 \mu \mathrm{m}$, 宽 40 80 $\mu \mathrm{m}$ ). 树 权为细长圆棒状, 向上三维分叉, 主要是包覆在颗粒的表面, 对胶结物起到粘结和固结作用 (图 7A). 缠绕式 生长的微生物也能够在碎屑颗粒表面上生长. 杂乱的菌丝(宽 $1 \sim 2 \mu \mathrm{m}$ ) 包裹着泥晶方解石和黏土矿物, 菌丝 将方解石粘结在一起 (图 7B). 此类微生物仅仅发育在等厚环边胶结物的泥晶方解石一层中. 等厚环边胶结 物的厚度越厚, 此类微生物越发育, 说明此类微生物对于胶结作用有着促进作用. 粘附式生长的微生物疑似 粗枝藻, 叶状体包含一个长长的中央茎, 中央茎周围生长着多个轮生的侧枝 (图 7C). 中央茎表面呈对称的 麦穗状 (图 7D), 叶状体表面凹凸不平, 呈半圆状的管腔, 其上附着大量疑似球状细菌 (具有较高的碳含量和 硫含量), 说明叶状体为其他的生物席居住者提供底质 (图 8A). 所有的微生物尚未完全被泥晶方解石交代, 碳的含量在 $80 \%$ 90\% 之间. 微生物的生长方式与胶结物组构存在着对应关系. 在等厚环边和栉壳状胶结物 中, 大量微生物附着在颗粒的表面上来吸附泥晶方解石颗粒和黏土矿物呈包壳生长. 在葡萄状胶结物中, 微 生物通过包裹泥晶方解石和黏土矿物的方式粘结颗粒.
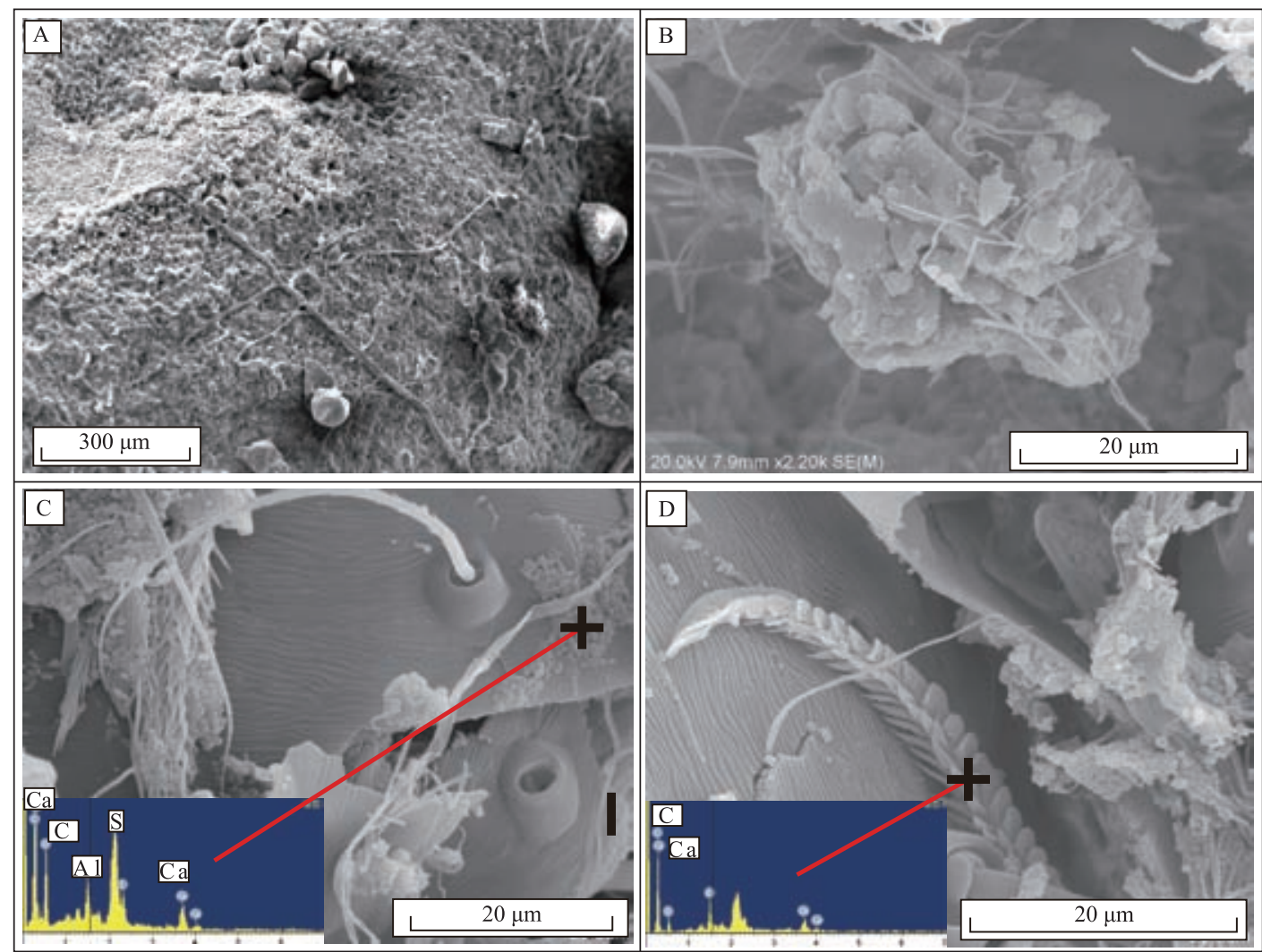

图 7 胶结物表面的扫描电镜照片: (A) 包覆式生长的微生物, 形态呈分叉状; (B) 缠绕式生长的微生物, 具有杂乱的菌丝; ( C ) 粘附式生长的微生物, 具有中央茎; ( D) 中央茎周围生长着多个轮生的侧枝

Fig.7 Surface view of beachrock cement under SEM photographs: (A) filaments on surface of grains.

Note large, euhedral carbonate crystals on the surface of grains; (B) carbonate crystals and clay twined by filaments; (C) adherent growth of microorganisms having a central stalk;

(D) the central stem surrounded by a plurality of whorled branches

此外, 利用显微薄片和扫描电镜观察, 不同类型的微生物生长方式影响着胶结物的形成. 当颗粒表面存 在凹槽时, 微生物生长过程中会向凹槽处聚集, 直至凹槽被填平, 形成一个光滑面 ( 图 3C1). 这种将凹槽填 
平的作用可被称为夷平作用 ${ }^{[34]}$. 当包覆式生长的微生物覆盖在颗粒表面时,网状化的微生物对于松散沉积 颗粒 (如方解石、黏土矿物等) 起到固定作用 (图 8B). 有的相对较粗的菌丝可作为网格的骨架 (图 8C). 这种 网格化的微生物还可以阻止松散的沉积颗粒被水流或波浪带走. 而在沉积颗粒表面再次覆盖这种网格化的 微生物会造成富含有机质的薄层软变形 (图 3 F1). 这种网格化的微生物固定松散沉积颗粒的作用可被称为 生物稳化作用 ${ }^{[34]}$. 有的细菌表面的菌丝会垂直于颗粒表面生长 (图 8D). 菌丝的集合体通过降低水流速, 从 而使水中的悬浮颗粒沉积下来的作用被称为障积作用和捕获作用. 随着微生物的继续直立生长, 菌丝捕获 的颗粒最终与微生物胶结在一起,这种作用可称为粘结作用 ${ }^{[34]}$.

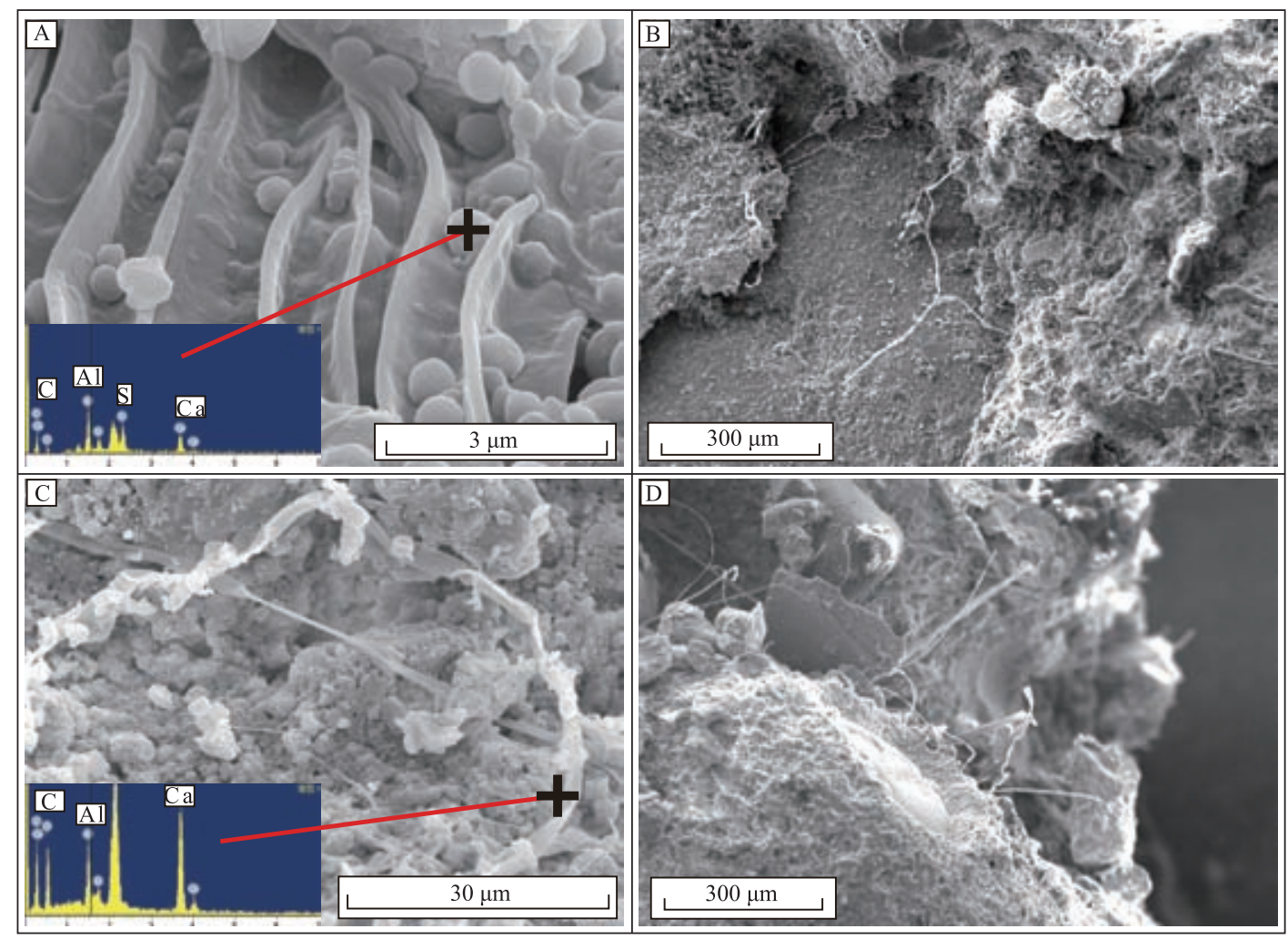

图 8 胶结物表面的扫描电镜照片: (A) 半圆状的管腔内附着大量疑似球状细菌;

(B) 网格化的微生物紧贴颗粒表面生长; ( C) 充当骨架的微生物菌丝;

(D) 垂直颗粒表面生长的菌丝, 起到降低水流速, 并使悬浮颗粒沉积下来

Fig. 8 Surface view of lake beachrock cement under SEM photographs:(A) a large number of suspected globular bacteria are attached to the semicircular lumen; (B) gridding microorganisms cling to the surface of particles;

(C) a microbial mycelium that acts as a skeleton; (D) the mycelium growing on a vertical particle surface reduces the flow velocity and deposits the suspended particles

\section{4 青海湖湖滩岩的变化规律和形成过程}

\section{1 湖滩岩的变化规律}

湖滩岩在垂向上和横向上的变化都存在着有规律的变化. 以二郎剑湖滩岩为例, 底部发育以文石针为 主的等厚环边胶结物, 中部为明暗纹层交替出现的栉壳状胶结物, 顶部为以黏土矿物为主的等厚环边胶结 物, 孔隙被大量陆源碎屑充填 (图 9). 从青海湖现今湖岸线位置到远离湖岸线的湖滩岩横向剖面可以划分 成五个部分 (图 10). 最靠近现今湖岸线的 A 处湖滩岩, 胶结物以杂乱的文石针为主, 是胶结物形成的最初 
形态. B 处湖滩岩胶结物以纤维状的晶体为主, 其生长和发育受到晶型的控制. C 处湖滩岩的胶结物以叶片 状晶体为主, 是全区湖滩岩胶结最好的部位. D 处湖滩岩的胶结物以等厚环边胶结物为主, 胶结物之间的孔 隙较大. $\mathrm{E}$ 处湖滩岩的胶结物以等厚环边胶结物为主, 具有较高的黏土含量. 胶结物从湖岸线到陆地的变 化, 指示了越靠近陆地, 越受到陆源碎屑的影响.

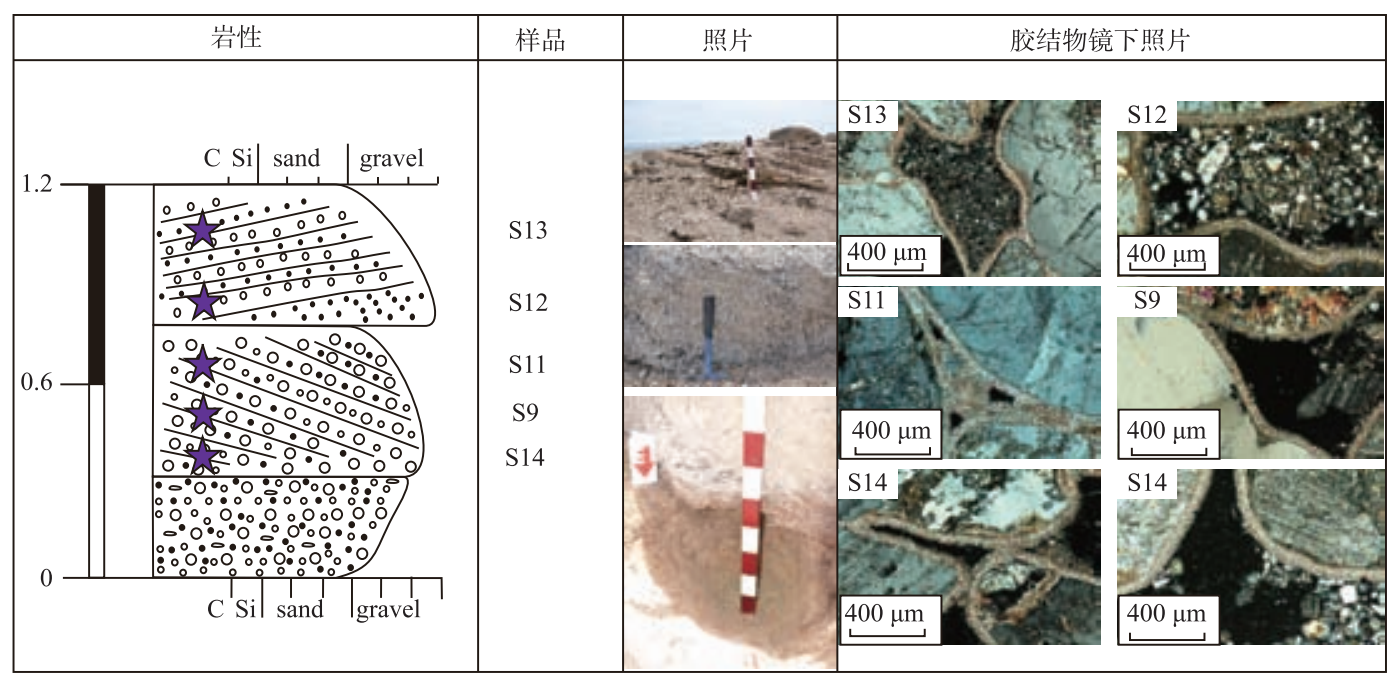

图 9 青海湖二郎剑湖滩岩胶结物垂向上变化图

(五角星指示了湖滩岩的采样位置, 位于图 10 的红色柱子位置)

Fig.9 The vertical lithological map of lake beachrock in Erlangjian of Lake Qinghai(View of studied lake beachrock. Stars indicate sampling locations. This photo is in the red part of Fig.10)

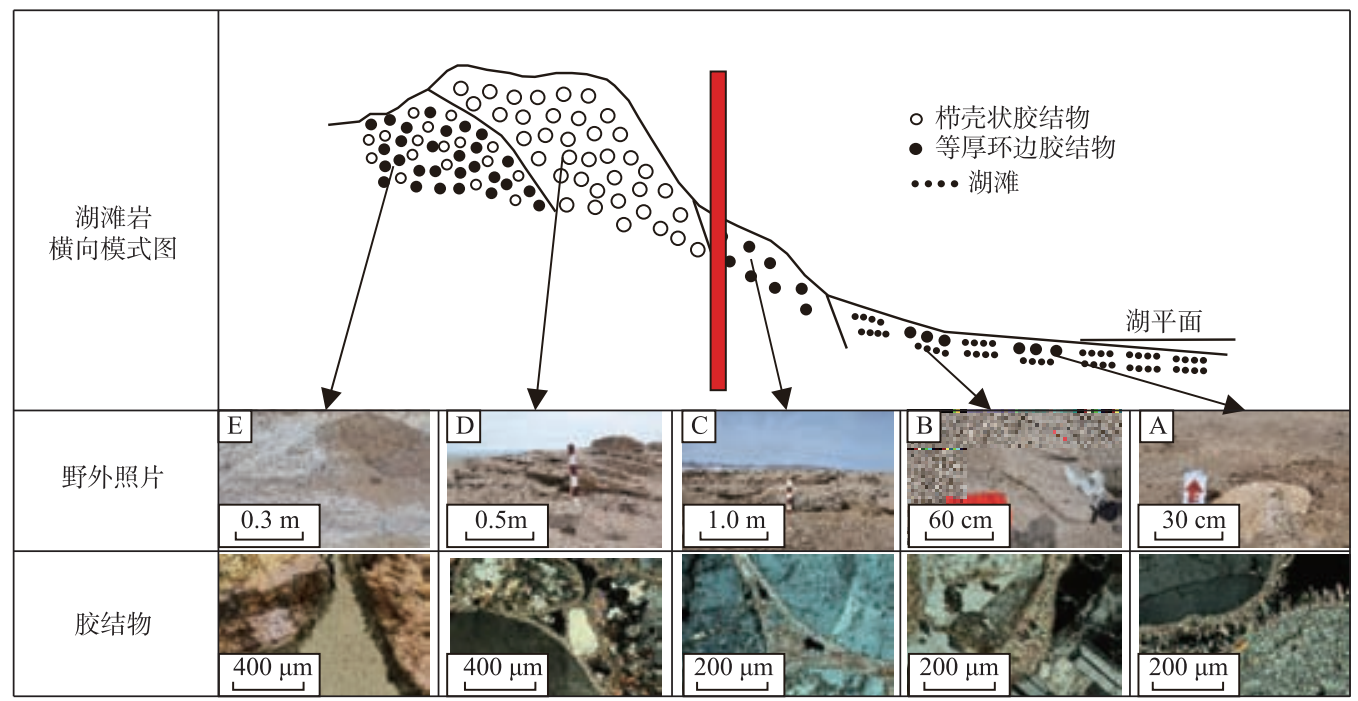

图 10 青海湖二郎剑湖滩岩胶结物横向上变化图

Fig.10 The horizontal lithological map of lake beachrock in Erlangjian of Lake Qinghai

\section{2 湖滩岩的形成过程}

通过显微镜和扫描电镜观察, 胶结物包括生物残体、泥晶方解石、黏土矿物和文石以及少量的石英颗粒. 
微生物在湖滩岩的形成过程中起到十分重要作用. 丝状细菌和球状细菌之间的交互式覆盖过程中产生了明 暗纹层的交替出现. 在泥晶包壳中, 丝状细菌占主导 (这是适应较低光照度的微生物), 吸附黏土矿物; 在浅 色纹层中, 球状细菌占主导, 吸附原地形成的碳酸盐岩颗粒. 当水体透明度高, 浊度低, 光照较低, 青海湖受 底层水湍流的影响, 扰动底泥和营养盐的释放, 促进丝状微生物的发育; 当水体透明度降低, 浊度上升, 光照 较高, 持续动荡的水动力环境促进球状细菌发育. 这些现象的出现揭示了重要的环境参数: (1)宁静的超盐度 浅水背景; (2)季节性旋回控制下的较低和较高的蒸发速度交替变化; (3)控制微生物发育的水位、盐度、光照 强度变化. 湖滩岩的演变过程经历了以下三个阶段（图 11) : (1)早期松散沉积物, 颗粒与颗粒之间无固结; (2)早期成岩阶段早期, 以微生物作用为主, 颗粒与颗粒之间生成微生物席, 其主要成分为黏土矿物、碳酸盐 矿物等; (3)早期成岩阶段晚期, 以微生物作用为主,化学作用为辅,形成等厚环边胶结物.

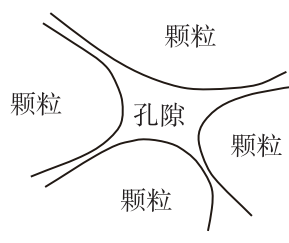

原始松散 沉积物阶段

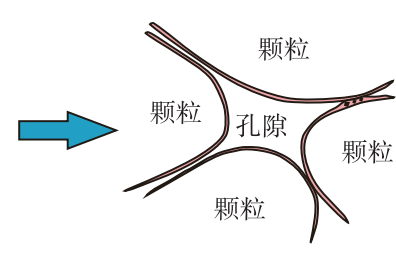

颗粒

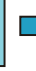

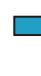

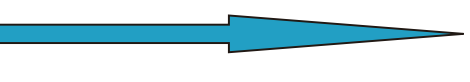

图 11 青海湖湖滩岩胶结物的形成过程
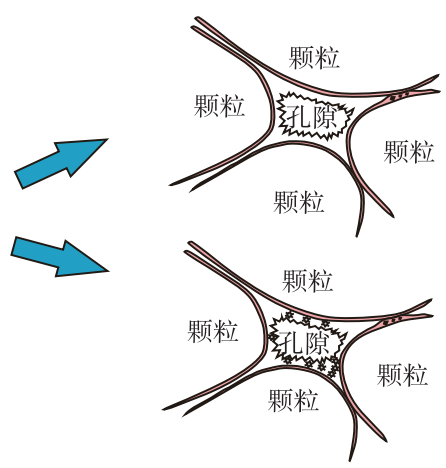

固结成湖滩岩

Fig.11 The diagenetic evolution of lake beachrock in Lake Qinghai

在不同的生态条件下, 如不同水深、温度、盐度、水动力环境, 湖滩岩胶结物的类型和组成也是不同的. 青海湖的水质参数垂直特征, 表现为水深与温度、盐度呈负相关 ${ }^{[35]}$. 按照湖泊滨岸带水动力分带的原则, 可 分为风暴带、破浪带、碎浪带和冲流一回流带 ${ }^{[31]}$. 破浪带和碎浪带的水深、温度、盐度适宜, 为微生物作用最 强的水动力带. 当水深大于浪基面的深度时 (即风暴带), 溶解氧的浓度大幅度下降, 浊度较高, 微生物作用 较弱. 当水深处于浪基面到一个波高之间时, 水体波动性增强, 水体融合较好, 溶解氧浓度较高, 微生物作用 发育, 形成以杂乱针状和纤维状晶体为主的等厚环边胶结物. 当水深处于一个波高到枯水面之间时, 水体波 动性进一步增强, 光照作用强, 温度和盐度适宜, 微生物作用十分发育, 形成以共轴柱状、叶片状和扇状晶体 为主的栉壳状胶结物. 在冲浪一回流带内, 相对缺少湖水的供给, 长时间暴露, 微生物作用很弱, 再加上陆源 碎屑物质的影响,形成以黏土矿物为主的等厚环边胶结物 (图 12).

\section{5 结论}

1) 在青海湖的现今湖岸线发现极为罕见的湖滩岩沉积, 并识别出五类胶结物晶体和三类胶结物组构. 在胶结物的暗色纹层中发现包覆式和缠绕式生长的微生物. 微生物对泥晶方解石和黏土矿物起到生物稳定 化作用 (障积作用、捕获作用和粘结作用). 微生物席生长过程中的新陈代谢影响碳酸盐的溶解度, 从而导致 产生碳酸盐矿物在微生物席内的丝状体之间或沿着丝状体的沉淀作用.

2) 从研究湖滩岩胶结物垂向上和横向上的变化规律人手, 发现胶结物的类型和组构与水深、温度、盐 度、水动力条件有一定关系. 湖滩岩胶结物形成的环境参数包括宁静的超盐度浅水背景、蒸发速度、水位、盐 度、光照等. 湖滩岩的演化过程可分为三个阶段, 微生物作用主要发生在早成岩阶段早期. 破浪带和碎浪带 的水深、温度、盐度适宜, 为微生物作用最强的水动力带.

3 ) 通过对青海湖湖滩岩微生物作用特征, 尤其是发育模式的研究, 认定湖滩岩中胶结物的沉积作用受 


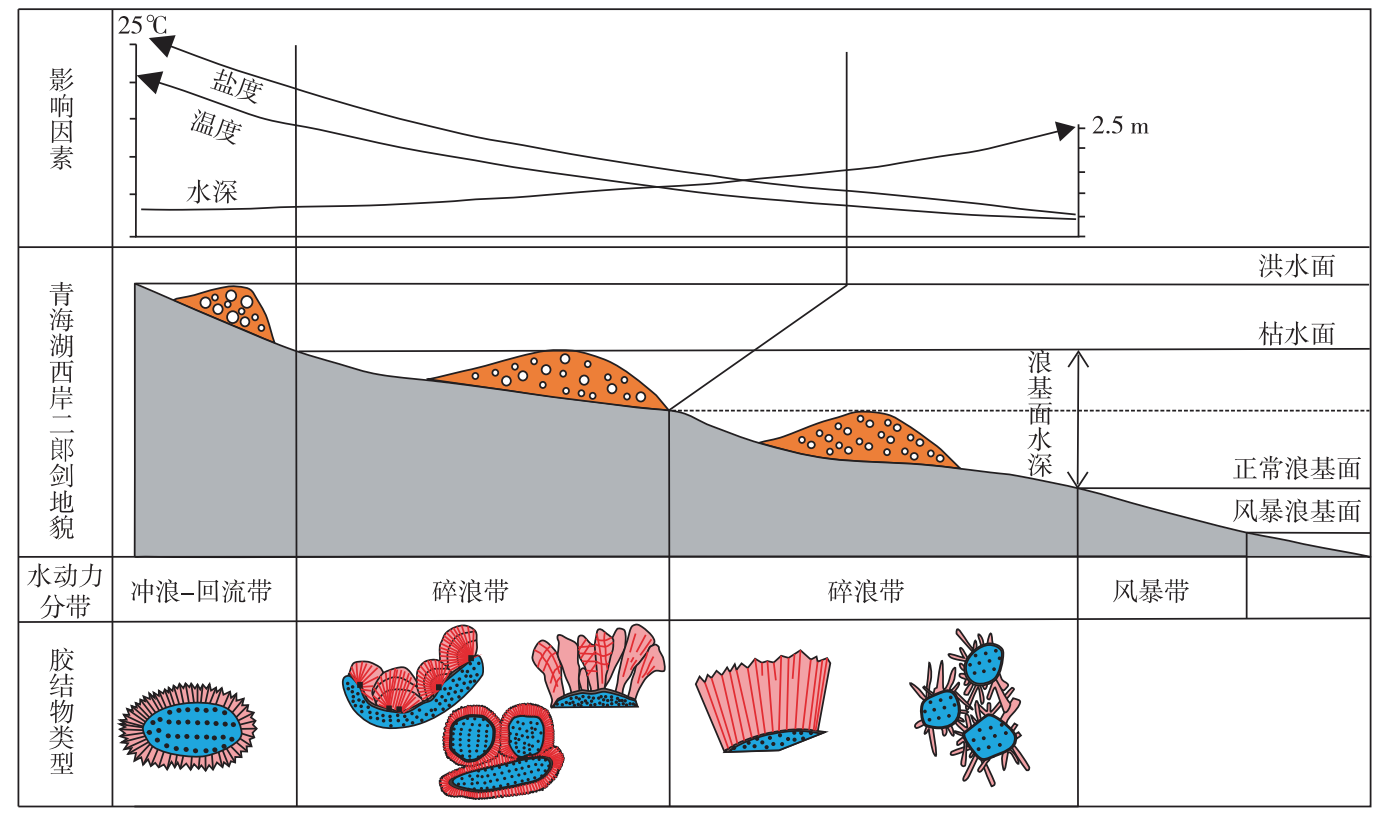

图 12 青海湖湖滩岩胶结物与水深、温度、盐度、水动力之间的关系

Fig. 12 The relationship between the cement of lake beachrock in Lake Qinghai and water depth, temperature, salinity and hydrodynamics

到微生物作用的影响较大. 该发现支持了湖滩岩的胶结物部分是源于微生物成因的,也支持了微生物作用 对碎屑岩早期成岩具有重要意义的假设.

\section{6 参考文献}

[ 1 ] Morse WJ, Mackenzie TF eds. Developments in sedimentology, Volume 48. New York: Elsevier, 1990: 241-276.

[ 2 ] Webb GE, Jell JS, Baker JS. Cryptic intertidal microbialites in beachrock, Heron Island, Great Barrier Reef: Implications for the origin of microcrystalline beachrock cement. Sedimentary Geology, 1999, 126(1/2/3/4) : 317-334. DOI: 10. 1016/s0037-0738(99)00047-0.

[ 3 ] Kelly CS, Green AN, Cooper J et al. Beachrock facies variability and sea level implications: a preliminary study. Journal of Coastal Research, 2014, 70: 736-742. DOI: 10.2112/SI70-124.1.

[ 4 ] Calvet F, Cabrera MC, Carracedo JC et al. Beachrocks from the island of La Palma(Canary Islands, Spain). Marine Geology, 2003, 197(1/2/3/4) : 75-93. DOI: 10.1016/S0025-3227(03)00090-2.

[ 5 ] David P, Konstantinos A, Nikoleta Z. Clastic sedimentary features of beachrocks and their palaeo-environmental significance: comparison of past and modern coastal regimes. International Journal of Sediment Research, 2014, 29(2) : 260268. DOI: $10.1016 / \mathrm{S} 1001-6279$ (14)60041-X.

[6] Takashi D, Satoru K. Characteristics of Beachrocks: A review. Geotechnical and Geological Engineering, 2014, 32(2): 215-246. DOI: 10.1007/s10706-013-9712-9.

[ 7 ] Vousdoukas MI, Velegrakis F, Paul M et al. Field observations and modeling of wave attenuation over colonized beachrocks. Continental Shelf Research, 2012, 48: 100-109. DOI: 10.1016/j.csr.2012.08.015.

[ 8 ] Vousdoukas MI, Velegrakis F, Plomaritis T. Beachrock occurrence, characteristics, formation mechanisms and impacts. Earth-Science Reviews, 2007, 85(1-2) : 23-46. DOI: 10.1016/j.earscirev.2007.07.002.

[ 9 ] Mauz B, Vacchi M, Green A et al. Beachrock: A tool for reconstructing relative sea level in the far-field. Marine Geology, 2015, 362: 1-1. DOI: 10.1016/j.margeo.2015.01.009.

[10] Rey D, Rubio B, Bernabeua et al. Formation, exposure, and evolution of a high-latitude beachrock in the intertidal zone 
of the Corrubedo complex( Ria de Arousa, Galicia, NW Spain). Sedimentary Geology, 2004, 169(1/2) : 93-105. DOI: 10.1016/j.sedgeo.2004.05.001.

[11] ShenHJ, Wang XL. The discovery of submerged late-pleistocenebeachrock on the southern margin of the East China sea continental shelf and its geological significance. Acta Sedimentologica Sinica, 1999, 17(S1) : 782-788. [ 沈浩杰, 王先兰. 东海大陆架南部边缘晚更新世淹没海滩岩的发现及其地质意义. 沉积学报, 1999, 17(S1) : 782-788.]

[12] Sun JL, Xu HL. Advances of beach rock research in China. Journal of Tropical Oceanography, 2009, 28(2) : 103-108. [孙金龙, 徐辉龙. 中国的海滩岩研究与进展. 热带海洋学报, 2009, 28(2): 103-108.]

[13] Huang Y, Lu X, Ding X et al. Natural radioactivity level in beach sand along the coast of Xiamen Island, China. Marine Pollution Bulletin, 2015, 91(1) : 357-361. DOI: 10.1016/j.marpolbul.2014.11.046.

[14] Jones B, Rosen MR, Renaut RW. Silica-cemented beachrock from Lake Taupo, North Island, New Zealand. Journal of Sedimentary Research, 1997, 67(5) : 805-814. DOI: 10.1306/D4268644-2B26-11D7-8648000102C1865D.

[15] Swainson IP. The structure of monohydrocalcite and the phase composition of the beachrock deposits of Lake Butler and Lake Fellmongery, South Australia. American Mineralogist, 2008, 93(7) : 1014-1018. DOI: 10.2138/am.2008.2825.

[16] Binkley KL, Wilkinson BH, Owen RM. VadoseBeachrock Cementation along a Southeastern Michigan Marl Lake. Journal of Sedimentary Research, 1980, 50(3) : 953-961.

[17] Last FM, Last WM, Halden NM. Carbonate microbialites and hardgrounds from Manito Lake, an alkaline, hypersaline lake in the northern Great Plains of Canada. Sedimentary Geology, 2010, 225(1/2) : 34-49.

[18] Dupraz C, Reid RP, Braissant O et al. Processes of carbonate precipitation in modern microbial mats.Earth-Science Reviews, 2009, 96(3): 41-162. DOI: 10.1016/j.earscirev.2008.10.005.

[19] Erginal AE, Kiyak NG, Ozturk MZ et al. Cementation characteristics and age of beachrocks in a fresh-water environment, Lake Iznik, NW Turkey. Sedimentary Geology, 2012, 243/244: 148-154. DOI: 10.1016/j.sedgeo.2011.10.012.

[20] Ozturk MZ, Erginal AE, Kiyak NG et al. Records of repeated drought stages during the Holocene, Lake Iznik ( Turkey) with reference to beachrock. Quaternary International, 2016, 408(SI) : 16-24. DOI: 10.1016/j.quaint.2015.08.077.

[21] Li YC. Comparing researchbeachrock in the south of Fujian Province and Lake Qinghai. Journal of Quanzhou Normal University: Natural Science, 2003, 21(4) : 43-47. [李永春. 闽南海滩岩与青海湖湖滩岩的比较研究. 泉州师范学院学 报: 自然科学, 2003, 21(4): 43-47.]

[22] Zhu DG, Zhao XT, Meng XG et al. Late Pleistocene Lacustrine-beach Rock around the Nam Co in Xizang. Geological Review, 2003, 49(4) : 432-438. DOI: 10.16509/j.georeview.2003.04.014. [ 朱大岗, 赵希涛, 孟宪刚等. 西藏纳木错晚 更新世湖滩岩. 地质论评, 2003, 49(4): 432-438.]

[23] Zhu DG, Zhao XT, Meng XG et al. On the quaternary lacustrine deposits and the lacustrine landform of Nam Co, Xizang (Tibet). Journal of Jilin University: Earth Science Edition, 2003, 33(2): 156-162. [ 朱大岗, 赵希涛, 孟宪刚等. 西藏 纳木错第四纪湖泊沉积与湖成地貌——兼论藏北高原古大湖问题. 吉林大学学报: 地球科学版, 2003, 33(2): 156-162.]

[24] Chen MY, Xu SL, Wu ZH et al. The features and ages of lake beach rock around Sayram Lake in Western Tian Shan and its significance on lake level fluctuation during the last interglacial Epoch Mis3. Journal of Geomechanics, 2014, 20(2) : 174-184. [陈明勇, 徐胜利, 吴中海等. 新疆赛里木湖的湖滩岩特征、时代及其对 MIS3 阶段湖面变化的指示意义. 地质力学学报, 2014, 20(2): 174-184.]

[25] Chen KZ, Huang DP, Liang DG. The formation and development of Lake Qinghai. Acta Geographica Sinica, 1964,30 (3) : 214-233. [陈克造, 黄第藩, 梁狄刚. 青海湖的形成和发展. 地理学报, 1964, 30(3) : 214-233. ]

[26] Lanzhou Institute of Geology, Institute of Aquatic Biology, Institute of Microbiology of Chinese Academy of Sciences et al eds. Comprehensive survey report of Lake Qinghai. Beijing: Science Press, 1979: 4-25. [中国科学院兰州地质研究所, 中国科学院水生生物研究所, 中国科学院微生物研究所等. 青海湖综合考察报告. 北京: 科学出版社, 1979: 4-25.]

[27] Lanzhou Institute, Research Center of Resources and Environment of Western China of Chinese Academy of Sciences eds. Evolution and prediction of modern environment in Lake Qinghai. Beijing: Science Press, 1994: 10-30. [中国科学院兰 州分院, 中国科学院西部资源环境研究中心. 青海湖近代环境的演化和预测. 北京: 科学出版社, 1994: 10-30.]

[28] Song CH, Wang XM, Shi YM et al. Sedimentary characteristics and mircrofacies of shore zone in Lake Qinghai. Acta Sedimentologica Sinica, 1999, 17(1) : 51-57. [ 宋春晖, 王新民, 师永民等.青海湖现代滨岸沉积微相及其特征. 沉积学 
报, 1999, 17(1): 51-57. ]

[29] Wang XM, Song CH, Shi YM et al. Modern sedimentary environment and sedimentary facies characteristics in Lake Qinghai. Acta Sedimentologica Sinica, 1997, 15(S1) : 157-162. [王新民, 宋春晖, 师永民等. 青海湖现代沉积环境与沉积 相特征. 沉积学报, 1997, 15(S1): 157-162.]

[30] Bureau of Geology and Mineral Resources of Qinghai Province ed. Regional geology of Qinghai Province. Beijing: Geological Publishing House, 1991：1-379. [青海省地质矿产局. 青海省区域地质志. 北京: 地质出版社, 1991: 1-379.]

[31] Jiang ZX ed. Sedimentology. Beijing: Petroleum Industry Press, 2003: 50-53. [姜在兴. 沉积学. 北京: 石油工业出版 社. 2003: 50-53.]

[32] Lan YF, Huang SJ, Huang KK et al. Cathodoluminescence features and diagenetic stage division of carbonates in the Zhujiang Formation, Pearl River Mouth Basin. Petroleum Geology and Recovery Efficiency, 2017, 24(1) : 34-42. [兰叶芳, 黄思静, 黄可可等. 珠江口盆地珠江组碳酸盐岩阴极发光特征及成岩阶段划分. 油气地质与采收率, 2017, 24 (1) : 34-42.]

[33] Lan YF, Huang SG, Ren SM et al. Diagenesis of middle permian carbonate rocks in Bijie Area, Northwestern Guizhou. Xingjiang Petroleum Geology, 2018, 39(5) : 507-516. [兰叶芳, 黄树光, 任戍明等. 黔西北毕节地区中二叠统碳酸 盐岩成岩作用. 新疆石油地质, 2018, 39(5): 507-516.]

[34] Mei MX. Feature and nature of microbial-mat: Theoretical basis of microbial-mat sedimentology. Journal of Palaeogeography, 2014,16(3) : 285-304. [ 梅冥相. 微生物席的特征和属性: 微生物席沉积学的理论基础. 古地理学报, 2014, 16(3) : 285-304.]

[35] Bi RX, Zhang HC, Li HY et al. Characteristics and changes of water quality parameters of Lake Qinghai in 2015. Journal of Water Resources Research, 2018, 7(1): 74-83. DOI: 10.12677/jwrr.2018.71009. [毕荣釒金, 张虎才, 李华勇等. 青 海湖 2015 年水质参数特征及其变化. 水资源研究, 2018, 7(1): 74-83.] 